\title{
TREŚCI LEGITYMIZACJI KAŻDEJ WŁADZY WARUNKIEM AKCEPTACJI JEJ POZYCJI USTROJOWEJ I WPŁYWÓW
}

Racja mocniejszego zawsze jest lepsza.

\section{Zakresy rozważań}

Pozycja i wpływy każdej władzy, poczynając od władzy rodzicielskiej aż do władzy państwowej, zależy od treści ich legitymizacji. Wśród różnych rodzajów legitymizacji poważne miejsce przypada legitymizacji władzy państwowej, szczególnie władzy wykonawczej, zarówno w jej normatywnym, jak i empirycznym sensie. Legitymizacja normatywna władzy państwowej czyni z niej powinność, zaś legitymizacja empiryczna potwierdza jej akceptację społeczną. Gdy demokratyczna forma władzy państwowej zabiega o przyzwolenie społeczne na jej sprawowanie, państwowa władza dyktatorska, autorytarna i totalitarna, nie mając takiego przyzwolenia, musi wspierać się ideologiami i przymusem ${ }^{1}$. Ta pierwsza może pretendować do wzoru legitymizacji, ponieważ uprawnienia władców do podejmowania politycznie wiążących decyzji politycznych uzależnia od aprobaty podwładnych. Natomiast te wspomniane poza nią narzucają podwładnym swoje decyzje polityczne bez ich na to zgody $^{2}$.

Legitymizacja władzy państwowej zatem to uzasadnienie racji jej źródeł, istnienia, treści i celów. Można by snuć rozważania na temat jakiejś proporcjonalności uzasadnień władzy państwowej do ich form ${ }^{3}$. Wprawdzie, jak dotychczas, żadna z form władzy państwowej nie ostawała się bez jakiejś jej legitymizacji, jednakże ich uzasadnienia ideologiczne bywają zróżnicowane pod wieloma względami. Ze

$1 \quad$ Por. np. W. Kosiakiewicz, Spór o terminy polityczne, (w:) Demokracja, demagogia i hemofilia, Warszawa 1913.

2 Trafna jest ocena, że „W samej naturze ludzkich wytworów nie ma niczego takiego, co przesądza, że wszystkie różnice są różnicami stopnia - tak jak w samej naturze rzeczy nie ma niczego takiego, co przesądza, że mają charakter jakościowy. Różnice dotyczą stopnia, gdy są tak traktowane (logicznie)". G. Satori, Teoria demokracji, Warszawa 1994, s. 231.

3 Literatura filozoficzna i naukowa dotycząca zakresów władzy jest ogromna, ponieważ narasta w całych niemal dziejach ludzkości. Z ogólnych, całościowych opracowań por. np. D.H. Wrong, Power. Its Form, Bases and Uses, Chicago 1988; także A. Antoszewski, Reżim polityczny, (w:) A. Jabłoński, L. Sobkowiak (red.), Studia z teorii polityki, Wrocław 1998; D. Minich, Władza państwowa w koncepcjach Grzegorza Leopolda Seidlera, Rzeszów 2013. 
względu na moc perswazyjną tych uzasadnień, kierowanych bardziej do podwładnych niż władców, trudno byłoby ustalić jakąś trwałą hierarchię legitymizacji władzy państwowej. Mimo że współcześnie legitymizacja demokratycznej formy władzy państwowej w skali globu dominuje zdecydowanie nad legitymizacjami innych form władzy państwowej, to jednakże i one znajdują przecież swoich zwolenników.

To, że każda władza państwowa potrzebuje legitymizacji jest przejawem nie tyle jej siły, ile słabości. Celem bowiem każdej legitymizacji jest bardziej osłanianie jej słabości, jako źródła ewentualnego braku posłuchu władzy państwowej ze strony podwładnych, niż ukazywanie oczywistej, na ogół, konieczności jej istnienia. Gdyby władza państwowa nie miała słabych stron - zbędna byłaby jej legitymizacja. Uzasadniałaby się per se $e^{4}$. Uzasadnienia różnych form władzy państwowej rysują się wyraźnie w ich relacjach.

Relacja to, inaczej, stosunek czegoś do czegoś, tutaj - dyktatury do autorytaryzmu i totalitaryzmu, autorytaryzmu do dyktatury i totalitaryzmu, totalitaryzmu do dyktatury i autorytaryzmu, a wszystkich tych pojęć do pojęcia demokracja. Stosunek ten może objawiać się w zależności wzajemnej owych pojęć, polegającej na uwarunkowaniach istnienia jednych od istnienia drugich, pokrywaniu, czy też krzyżowaniu się częściowych zakresów ich treści. Relacja zakłada celowość porównywania, komparatystyki pojęć pozostających ze sobą w określonej relacji. Rezultaty komparatystyki prowadzą do stwierdzania tożsamości, podobieństw i różnic, pozostających we wzajemnych relacjach pojęć, w naszym przypadku - dyktatury, autorytaryzmu i totalitaryzmu. Mogą być stwierdzone następujące możliwości rezultatów komparatystyki: tylko tożsamości, tylko podobieństwa, tylko różnice; tożsamości i podobieństwa; tożsamości i różnice; podobieństwa i różnice; tożsamości i podobieństwa, i różnice. Stwierdzenie: tożsamości, przynajmniej w pewnym zakresie pojęć, pozwala na wspólną ich charakterystykę w tym zakresie; podobieństwa - skłania do wykazania przewagi cech wspólnych nad cechami różnymi; różnic - do uzasadnienia przewagi tego, co odmienne nad tym, co podobne 5 .

Władza jest zapewne relacją władców - posiadaczy władzy z podwładnymi - pozbawionymi jej posiadania. Polega na narzucaniu woli tych pierwszych tym drugim, przy pomocy środków politycznych, a więc głównie państwowych. Podwładni mogą dobrowolnie poddawać się władzy, gdy uznają jej autorytet, legalizm, moralizm czy sakralizm albo, gdy tego nie czynią, ulegać jej pod przymusem psychicznym albo (i) fizycznym. Władza występuje w każdej grupie społecznej i różnych

Szeroko uznawaną koncepcję legitymizacji władzy opracował Max Weber, Trzy typy prawomocnego panowania (w:) Elementy teorii socjologicznych, W. Derczyński, A. Jasińska-Kania, J. Szacki (red.), Warszawa 1975; por. również T. Biernat, Legitymizacja władzy politycznej. Elementy teorii, Toruń 1999; R. Tokarczyk, Współczesne doktryny polityczne, wydanie XVI poszerzone, Warszawa 2010, s. 25 i n.

$5 \quad$ Komparatystyka, zwana jest inaczej literaturą porównawczą, jest uprawiana nie tylko w literaturze pięknej lecz również i literaturze naukowej. Dla naszego tematu niezbędne są elementy komparatystyki politologicznej. $\mathrm{Na}$ ten temat por. np. R. Tokarczyk, Metody porównawcze w historii doktryn politycznych i prawnych, „Biuletyn Lubelskiego Towarzystwa Naukowego - Humanistyka" 1984, vol. 26, nr 2; także R. Tokarczyk, Komparatystyka prawnicza, wyd. IX, Warszawa 2008. 
rodzajach aktywności ludzi. Najważniejszą jednak rolę odgrywa władza polityczna. Od czasu wprowadzenia zasady trójpodziału władzy w demokratycznych ustrojach państwowych, realizowana jest ona za pośrednictwem władzy ustawodawczej należącej do parlamentów, władzy wykonawczej przekazywanej rządom albo (i) prezydentom i władzy sądowniczej oddawanej niezawisłym sądom. Bez względu na jednolitość czy też podział władzy, spełniać ona może funkcje integracji społeczeństwa, podziału dóbr i kar, ochrony przed zagrożeniami zewnętrznymi i wewnętrznymi i tworzenia niezbędnych organizacji i struktur. Mimo ogromnej liczby dzieł filozoficznych, teologicznych i naukowych poświęconych władzy, nadal należy ona do najtrudniejszych problemów wielu nauk, szczególnie nauk politycznych. Ludzie od tysięcy lat starają się przeniknąć istotę władzy, ale z umiarkowanym powodzeniem. Władza polityczna poddawana jest zróżnicowanym ocenom, często skrajnym - od zachwytów jej posiadaczy po oceny skrajnie negatywne, formułowane przez tych, którzy jej nie mają, ale pragną ją mieć.

\section{Kluczowe pojęcia}

Pojęcie „władza” jest nadzwyczaj rozległe, toteż jest źródłem dużej rodziny związanych z nią innych pojęć. Rodzina tych pojęć jest nadal duża, nawet jeśli pojęcie władza w ogóle ograniczamy, jak tutaj, do pojęcia władzy państwowej i tylko dwóch jej przejawów - idei i ustroju państwowego, czy też reżimu politycznego gdy będziemy posługiwać się tym określeniem w sposób neutralny albo ocenny. Dla opisu i komparatystyki pojęć dyktatura, autorytaryzm i totalitaryzm, na tle pojęcia demokracja, jak dla wszelkiej komparatystyki, niezbędne jest podanie jej kryteriów, czyli podstawy. Wydaje się, że najbardziej odpowiednimi kryteriami dla komparatystyki pojęć związanych z władzą w ogóle, w szczególności zaś pojęć dyktatura, autorytaryzm i totalitaryzm, są kryteria ich podmiotu, suwerenności, legitymizacji, źródeł, przedmiotu, struktury i reżimu. Najbardziej atrakcyjne poznawczo jest charakteryzowanie owych kryteriów w ujęciu spektrum, rozciągającego się od skrajności określonego minimum, poprzez narastanie jego intensywności, aż po skrajność pewnego tego maksimum. Jednocześnie, w oparciu o różne kryteria aksjologiczne, można wskazywać na tym spektrum punkty rozgraniczające od siebie, np. legalne od nielegalnego, moralne od niemoralnego, sakralne od niesakralnego.

Spektrum podmiotów władzy, określone ze względu na pytanie, do kogo należy władza, rozciąga się od władzy jednostki poprzez władzę coraz to większej liczby jednostek, aż po ogół obywateli uprawnionych do współsprawowania władzy. W oparciu o podmiotowe kryterium władzy jednostek powstało wiele idei i ustrojów jedynowładzwa albo monokracji lub nomokracji - tyrania, satrapia, cesarstwo, cezaryzm, monarchia, carat, samodzierżawie, shogunat i inne. Gdy władza należy do dwóch osób to duowirat, trzech - triumwirat, przy większych liczbach podmiotów 
władzy mówi się demokracji przedstawicielskiej, timokracji, arystokracji, politei, mentokracji, oligarchii, demagogii, ochlokracji, dyktaturze, autokracji, totalitaryzmie i innych. Władza ogółu uprawnionych do niej obywateli nazywana jest najczęściej demokracją uczestniczącą albo demokracją partycypującą.

Suwerenność władzy państwowej jest zarówno ideą, jak i faktyczną cechą podmiotów tej władzy, wskazującą na zwierzchnictwo, niezależność w zakresie jej kompetencji, głównie kompetencji prawotwórczych. Jako faktyczna cecha władzy suwerenność występuje od samych początków władzy państwowej, natomiast jako idea pojawiła się w myśli politycznej dopiero od czasów koncepcji suwerenności przedstawionej w XVI stuleciu przez Jeana Bodina. Ta nowożytna koncepcja suwerenności zakłada celowość całkowitej, absolutnej niezależności i niepodległości podmiotów władzy państwowej; od kogokolwiek lub czegokolwiek; w średniowiecznym pojęciu zwierzchnictwo (seigneurie) - od cesarza, papieża, stanów i prawa zwyczajowego. Dla podmiotów władzy państwowej istotna jest suwerenność faktyczna, historycznie ukształtowana i rzeczywiście realizowana. Paradoksalność suwerenności podmiotów władzy w państwach współczesnych polega na tym, że własną suwerennością tworzenia prawa mimowolnie ograniczają one swoją suwerenność.

Legitymizacja władzy to wyraźne, domniemywane, lub milczące, uzasadnienie upoważnienia jej do sprawowania władzy, mające jednolity charakter sakralny, moralistyczny, legalistyczny lub jakichś ich połączeń 6 . Władza legitymizowana oczekuje dobrowolnej akceptacji i podporządkowania się jej przez podwładnych w zakresie nabycia, sprawowania i celów władzy. Oczywiście, podwładni, świadomi legitymizacji władzy, chętniej objawiają wobec niej posłuszeństwo, w przeciwieństwie do władzy pozbawionej jakiejkolwiek legitymizacji, np. władzy tyrana, opartej jedynie na przymusie. Zestawienie legitymizacji władzy z suwerennością władzy znowu wskazuje na pewien paradoks: władza suwerenna, czyli niezależna, powinna wprawdzie cieszyć się uznaniem podwładnych, ale jednocześnie na tyle nie uzależnić się od tego uznania, aby rzeczywiście mogła realizować swoją niezależność.

Źródła władzy są ważnym i interesującym kryterium dla komparatystyki różnych idei i praktyk władzy, zwłaszcza dyktatury, autorytaryzmu i totalitaryzmu. Według najstarszych poglądów starożytnych, mających największe znaczenie w Europie średniowiecznej, władza pochodzi od Boga, który przekazał ją władcom ziemskim, legitymizującym się w swoich działaniach boską charyzmą. Wśród licznych świeckich teorii źródeł władzy wspomnieć należy o poglądach: patriarchalnych - głoszących, że władza państwowa pochodzi od władzy ojca patriarchy nad członkami rodziny; patrymonialnych - kojarzących źródła władzy z własnością ziemi; podboju - wyja-

6 Ten mój pogląd na rodzaje legitymizacji różni się od rozpowszechnionego poglądu Maksa Webera, który wyróżnił trzy rodzaje legitymizacji władzy - charyzmatyczną, tradycjonalistyczną i legalistyczną oraz mniej znanego, ale interesującego, poglądu Davida Eastona, dostrzegającego potrzebę jednoczesnego istnienia legitymizacji ideologicznej, strukturalnej i personalnej. 
śniających powstawanie państw ujarzmianiem plemion albo ras słabszych przez plemiona lub rasy silniejsze; umowy społecznej - dopatrującej się początków państwa w umowie ludzi zawartej w stanie pierwotnym dotyczącej ustanowienia społeczeństwa i (albo) ustanowienia państwa; rozpadu społeczeństwa na klasy, powodującego sprzeczności klasowe i konieczność ich ujarzmiania siłą władzy państwowej; psychologicznych - uzasadniających źródła władzy czynnikami motywacji władców i podwładnych oraz socjologicznych - za decydujące uznających względy prawidłowego funkcjonowania społeczeństw, opartych, na przykład, na założeniach solidaryzmu społecznego ${ }^{7}$.

Przedmiot władzy państwowej określa jej rola w życiu społecznym, spełniane przez nią funkcje. Spektrum przedmiotu, roli, funkcji tej władzy rozciąga się od skrajności absolutyzmu i totalitaryzmu idei i praktyk władzy pragnącej decydować o wszystkich sprawach obywateli, poprzez idee i praktyki ograniczeń w tych względach, aż do idei i praktyk władzy minimalnej państwa liberalnego, z tego względu nazywanego, nieco pobłażliwie, ,stróżem nocnym”. Przedmiot, rola, funkcje władzy występują głównie wewnątrz państwa, natomiast na zewnątrz niego dotyczą one głównie bezpieczeństwa obywateli przed zagrożeniami militarnymi oraz dotyczą pokojowych stosunków handlowych i kulturowych z innymi państwami. Za najważniejsze funkcje wewnątrzpaństwowe władzy uznawane są zwykle funkcje organizacyjne, gospodarcze, socjalne, dystrybucyjne i represyjne.

Każda władza państwowa odznacza się właściwą jej organizacją, strukturą, budową, architekturą, formą jej organów. Za główną podstawę rozróżniania państw ze względu na ich organizację, strukturę, budowę, architekturę, formę, przyjmowana jest, wspomniana już wcześniej, liczba podmiotów władzy. Wspominaliśmy o trzech rodzajach tych podmiotów: jednostce - grupie, ogóle uprawnionych obywateli. Jedynowładztwo kształtuje władzę scentralizowaną i skoncentrowaną w rękach różnie nazywanych jedynowładców, z reguły zdobywających swoją władzę przemocą lub na zasadzie dziedziczenia. Władza małych grup rządzących zwykle pochodzi z przemocy, toteż dąży do centralizacji i koncentracji władzy w swoich rękach. Władza natomiast większych grup, jak w demokracji przedstawicielskiej, pochodzi z wyborów powszechnych. Zwana jest władzą republikańską, skłaniając się ku decentralizacji i dekoncentracji władzy na różnych poziomach jej przedmiotowej, terytorialnej, jednolitej albo federalnej, organizacji. Wreszcie, władza ogółu uprawnionych obywateli ową decentralizację i dekoncentrację władzy może chyba realizować najpełniej.

Metody sprawowania władzy państwowej można również nazywać, jak to już zaznaczono, reżimem politycznym, jeżeli odrzucimy jego sens pejoratywny, kojarzony z władzą ocenianą źle. Zależnie od metod sprawowania władzy państwowej, rozróżniane są władze demokratyczne i władze niedemokratyczne. Władza reżimów demokratycznych posługuje się nie tylko metodami legalnymi, ale i jednocześnie 
ocenianymi jako moralnie dobre. Władza zaś niektórych reżimów niedemokratycznych, jakkolwiek może pozorować legalizację stosowanych przez siebie metod, nie może jednak oczekiwać na pozytywną ich ocenę moralną. Niemoralnymi, chociaż na ogół legalizowanymi metodami, posługują się władze z kręgu idei i praktyk dyktatury, autorytaryzmu i totalitaryzmu. Charakter reżimu - demokratyczny albo niedemokratyczny, uznawany jest, dość zgodnie, w myśli filozoficznej i naukowej za jedno z głównych kryteriów odróżniania ustrojów dobrych od ustrojów złych. Jednocześnie należy wszakże podkreślić, że nawet reżimy demokratyczne jeszcze nie wypracowały dla siebie formy władzy na tyle dobrej i trwałej, aby uniknąć ich degeneracji we władzę złą.

\section{Legitymizacja demokracji}

Demokracja, w sensie idei i ustroju państwa, bardzo często, w aurze aprobaty, przeciwstawiana jest ideom i ustrojom państwowym zwanym dyktaturą, autorytaryzmem i totalitaryzmem. $Z$ tego ważnego powodu, mimo że temat nasz ma głównie na celu rozważanie pojęć dyktatura, autorytaryzm i totalitaryzm, potrzebne jest przynajmniej zwięzłe omówienie demokracji. Nazwa demokratia składa się ze słów języka greckiego demos - lud i kratos - władza, czyli w ich połączeniu władza ludu. W rozbudzaniu pozytywnych emocji demokratycznych, przeciwstawianych negatywnym emocjom niedemokratycznym, z szerokim uznaniem spotkała się definicja demokracji jako „rządy ludu, przez lud i dla ludu”, wypowiedziana przez Abrahama Lincolna, prezydenta Stanów Zjednoczonych ${ }^{8}$. Bardziej rozwinięta jest definicja Gentile Sartori'ego wyjaśniająca, że demokracja to system, w którym nikt nie może sam siebie wybrać, nikt nie może poszerzyć sobie władzy, rządzenia i tym samym nikt nie może przywłaszczyć sobie bezwarunkowej i nieograniczonej władzy. Trudności zadowalającego zdefiniowania demokracji wynikają przede wszystkim z wieloznaczności pojęcia „lud”, pojmowanego jako: wszyscy (obywatele, naród), bardzo wielu, klasy niższe, ograniczona całość, absolutna większość, ograniczona większość ${ }^{9}$. Skoro demokracja jest zawsze władzą w określony sposób pojmowanego ludu, nazwa „demokracja ludowa”, propagowana w ustrojach socjalistycznych, jest pleonazmem o cechach niezdarności semantycznej i stylistycznej.

Spektrum idei i (albo) ustroju demokracji przebiega od minimum demokracji pośredniej, przedstawicielskiej, reprezentacyjnej, poprzez optimum istniejących ustrojów demokracji bezpośredniej, aż do idei bardziej jeszcze ukształtowanych ustrojów demokracji uczestnictwa albo partycypacji w sprawowaniu władzy ogółu

8

9

Definicji tej sprzeciwiają się ci autorzy, którzy definiują demokrację jako system rządów z ludem, ale nie przez sam ten lud. Tak np. L.S. Amery, Rządność w demokracji: rozwiązanie brytyjskie, (w:) Demokracja a ideał społeczny, Londyn 1967.

Tak G. Sartori, Teoria demokracji, op. cit., s. 37 i nast., s. 257. Także m. in. D. Held, Models of Democracy, Stanford 1987; J. Zadencki, Wobec despotyzmu wolności, Kraków 1995; R. Dahl, O demokracji, Kraków 2000. 
uprawnionych do tego obywateli ${ }^{10}$. Ewolucja form demokracji rozpoczęła się od klasycznej jej formy greckiej, z najbardziej rozwiniętą demokracją ateńską. Późniejsze jej formy nieklasyczne to m.in.: staropolska demokracja szlachecka, szwajcarska demokracja kantonalna, amerykańska demokracja republikańska, demokracja narodowa, demokracja socjalistyczna, demokracja ludowa, demokracja chrześcijańska, demokracja personalistyczna i najnowsza demokracja powiązana z liberalizmem, zwana demokratycznym państwem prawnym albo demoliberalizmem. Demoliberalizm ma na celu równoważenie wolności i równości matematycznej większości społeczeństwa, toteż bywa określany jako demokracja numeryczna, albo nieco bardziej uszczypliwie, jako cyfrokracja.

Dość karkołomna jest natomiast propozycja wyodrębnienia demokracji totalitarnej, na ogół ocenianej jednak negatywnie, opartej na idei Jana Jakuba Rousseau „woli powszechnej”, bez większego powodzenia wprowadzanej do praktyki ustrojowej najpierw przez jakobinów, a później bolszewików ${ }^{11}$. Aprobata tej propozycji unicestwiałaby bowiem wszystkie jakże liczne poglądy i praktyki, uznające demokrację za przeciwieństwo totalitaryzmu i odwrotnie. Bardziej zatem przekonywująca jest koncepcja poliarchii, jako, według jej zwolenników, jedynie uzasadnionej współcześnie formy demokracji. Istota poliarchii wyrażać się ma w prawach obywatelskich większości społeczeństwa, zdolnej do przeciwstawienia się rządzącym, a nawet pozbawienia ich władzy poprzez głosowanie ${ }^{12}$.

Suwerenem, we wszystkich formach demokracji, jest wspominany już lud, pojmowany wszakże niejednoznacznie. Bez względu jednak na przyjęty sens pojęcia „lud”, w demokracji przynajmniej większość ludu występuje równocześnie w podwójnej roli - suwerena i suzerena, rządzących i rządzonych, chciałoby się wprost powiedzieć - samorządnych. Tutaj zatem chyba należy upatrywać przeciwieństwa demokracji do innych niedemokratycznych form władzy, w których władza należy do jednostki, małej grupy, a więc zawsze do określonej mniejszości, natomiast większość społeczeństwa jest w nich pozbawiona władzy. We wszystkich formach demokracji, władza jest legitymizowana na drodze wolnych i równościowych wyborów obywateli, wybierających rządzących - władzę, przy jednoczesnym wykluczeniu jej dziedziczenia, nominowania, powoływania. Demokracja ma źródła zarówno w ideach demokratycznych, rozwijanych od czasów starożytnych, po obecne czasy, jak i doświadczeniach ustrojów demokratycznych, zawsze przynajmniej deklaratywnie, zatroskanych o swoje podstawy prawne, zwykle konstytucyjne. Demokracje, na ogół, realizują podobne funkcje jak inne formy państwa, jednakże wyróżniają się wśród nich gwarancjami szerokich zakresów praw i wolności obywatelskich. Gwa-

\footnotetext{
10 Demokrację uczestnictwa przyjmowały ruchy Nowej Lewicy. Szerzej por. R. Tokarczyk, Utopia Nowej Lewicy Amerykańskiej, Warszawa 1979; R. Tokarczyk, Nowa Lewica, Warszawa 2010. Jakimś echem tego jest tzw. demokracja przemysłowa, wyrażająca się w różnych formach współzarządzania pracowniczego. Por. także M. Marczewska-Rytko, Demokracja bezpośrednia w teorii i praktyce politycznej, Lublin 2001.

11 Propozycję wysunął J.L. Talmon, The Origins of Totalitarian Democracy, London 1952.

12 Rozwinięcie koncepcji poliarchii dostępne jest na stronach Internetu pod hasłem „poliarchia”.
} 
rancje istnieją również dla mniejszości, które mimo że nie akceptują władzy, mają prawo do jej krytyki i oporu wobec niej, w granicach tzw. obywatelskiego nieposłuszeństwa. Organizacja, struktura, ustrój władzy w różnych demokracjach przybierały różne kształty, ale współczesne demokracje opierają swoją władzę głównie na wzorach demokracji parlamentarnej.

Metody kształtowania ładu społecznego, przyjmowane w demokracjach, uwarunkowane są zasadą trójpodziału władzy, mającą zapewniać równocześnie jej decentralizację i dekoncentrację. Demokratyczne reżimy polityczne, w pozytywnym sensie reżimu jako legalnego i moralnego sposobu sprawowania władzy państwowej, podlegają okresowym ocenom i odpowiedzialności w nadzwyczajnych sytuacjach ich nadużyć i kryzysów. Treści materialne władzy, zgodne z aksjologią demokratyzmu i liberalizmu, uzgadniane są z formalnymi procedurami jako metodami ich realizacji, którym również nadawany jest sens aksjologiczny. Ta proceduralna strona demokracji - demokratyzacja - skłania do ciągłego pogłębiania, rozwoju, dynamiki, impetyczności, imperialności, wręcz ,żarłoczności” władz demokratycznych „płynących na kolejnych falach demokratyzacji"' ${ }^{13}$. Skrajna demokratyzacja może paradoksalnie doprowadzać wręcz do totalności zakresów autorytarnej władzy, ukrywającej się za demokratycznym parawanem. Tutaj właśnie może następować niebezpieczne zbliżenie demokracji do dyktatury, zawsze antyliberalnej, ale niekoniecznie antydemokratycznej. Niekiedy łatwiej zyskać aprobatę ludu dla metod dyktatorskich, jak np. w nazizmie, niż dla metod liberalnych. Pogląd, że idea totalitaryzmu, w formie komunizmu, faszyzmu, nazizmu, wywodzić się może z koncepcji demokracji Jana Jakuba Rousseau jako woli ogółu ludu uchodzi wręcz za oczywistość dla wielu znawców myśli politycznej. Tak więc, nieliberalne znaczenia demokracji kontestować mogą jedynie: a) niepewni teoretycznych podstaw swojego antykomunizmu czy antyfaszyzmu (antynazizmu) antytotalitaryści; b) sentymentalni wielbiciele demokracji jako idealnej zasady zasad; c) wyraziciele sentymentalnego patosu liberalnego indywidualizmu ${ }^{14}$.

\section{Legitymizacja dyktatury}

Pojęcie dyktatura zawdzięcza swoją nazwę łacińskiemu słowu dictare, oznaczającemu dyktować, zalecać. Pojęcie to występuje wśród idei i praktyk politycznych od czasów starożytnej Grecji. Utożsamiane tam z tyranią, satrapią, despotią, zyskiwało aprobatę i szacunek w czasach dużego zagrożenia dla obywateli i państwa, ponieważ

Owa „żarłoczność” demokratyzacji bywa porównywana do zachowania nowotworu w organizmie biologicznym. Szerzej por. P. Huntington, Trzecia fala demokratyzacji, Warszawa 1995.

14 C. Schmitt, Sytuacja historyczna i stan duchowy dzisiejszego parlamentaryzmu, (w:) Konserwatyzm. Projekt teoretyczny, B. Markiewicz (red.), Warszawa 1995; podobnie M. Zdziechowski, Europa, Rosja, Azja, Wilno 1923; M. Staszewski, Demokracja a totalizm, Warszawa 1938; R. Aron, Democratie et Totalitarisme, Paris 1965. Omówienie tych poglądów daje J. Bartyzel, Demokracja, na stronach Internetu; Por. także G.L. Seidler, Władza ustawodawcza i wykonawcza w polskich konstrukcjach ustrojowych 1917-1947, Lublin 2000. 
kojarzyło się z silną władzą, zdolną do zapewnienia bezpieczeństwa ${ }^{15}$. W starożytnej republice rzymskiej dyktator (dictator) był urzędnikiem powoływanym na okres sześciu miesięcy dla ratowania zagrożonej republiki. Także przywódców polskiego Powstania Styczniowego nazywano dyktatorami jako osoby skupiające pełnię władzy w swoim ręku. Następnie pojęcie dyktatura nabrało negatywnego sensu rządów, czy też reżimu jednostki, albo grupy osób, które przejęły władzę siłą, w sposób niedemokratyczny, bezprawny, najczęściej na drodze zamachu stanu. Dyktator lub dyktatorzy arbitralnie wymuszają posłuch obywateli, jednocześnie pozbawiając ich możliwości kontrolowana swoich sposobów sprawowania dyktatorskiej władzy. W marksizmie, na gruncie ogólnego pojęcia dyktatury, rozwinęło się pojęcie dyktatura proletariatu jako władza klasy robotniczej, albo ludu pracującego miast i wsi, sprawowana w okresie przechodzenia od kapitalizmu do socjalizmu.

Współcześnie dominują idee i ustroje oparte na pojęciu demokracja, głównie demokracja konstytucyjna, realizująca zasadę podziału władzy na ustawodawczą, wykonawczą i sądowniczą. Tutaj przejawia się kontrastowa wręcz różnica między demokratyczną zasadą trójpodziału władzy a brakiem takiego podziału, czyli koncentracją pełnej, wyłącznej, nieograniczonej, nadzwyczajnej władzy w ręku dyktatora lub dyktatorów w reżimach dyktatorskich. Niekiedy, gdy reżimy dyktatorskie ograniczają zakresy swojej władzy do jednej albo dwóch jej rodzajów, mówi się o dyktaturach częściowych, albo mieszanych, łączących elementy dyktatury z elementami niedyktatorskimi, nawet $\mathrm{z}$ elementami demokracji. Istnieje pogląd, że demokracja przedstawicielska dość łatwo może przeobrażać się w dyktaturę, zwaną wówczas dyktaturą konstytucyjną. Do obecnego czasu brak jeszcze rozwiniętej teorii dyktatury. Antonio Gramsci nazywał dyktaturę hegemonią władzy niekonstytucyjnej, najczęściej jednopartyjnego reżimu państwowego ${ }^{16}$.

W praktyce politycznej pojęcie dyktatura przejawia się jako metoda sprawowania władzy albo ustrój polityczny. Przyjęcie kryteriów historycznej zmienności form dyktatury i sposobów przejmowania władzy stworzyło dla amerykańskich badaczy pojęcia dyktatura podstawę dla rozróżnienia dyktatur w ramach szerszego pojęcia autokracja (jedynowładztwo, nomokracja). Otóż, po rozróżnieniu autokracji przednowoczesnej i autokracji współczesnej, w ramach tej pierwszej umieścili oni dyktatury zwane despotyzmem, tyranią i absolutyzmem, natomiast do tej drugiej zaliczyli dyktatury teokratyczne i dyktatury totalitarne ${ }^{17}$. Włoski politolog G. Sartori pokla-

15 Szerzej por. m.in. G. Hallgarten, Devils and Saviours. A History of Dictatorship since 600 b C., London 1960; P. Vansittart, Doctators to 1995, London 1995.

16 Należy zauważyć zalążki teorii dyktatury w decyzjonistycznym nurcie konserwatyzmu, który wyrażali: Juan Donoso Cortes (1809-1853), hiszpański tradycjonalista katolicki, w jego tekście Discurso sobra la dictatura (1849), Charles Maurras (1868-1952), francuski rojalista, autor książki Dictateur et Roi (1899) i przede wszystkim Carl Schmitt (1888-1985), niemiecki konserwatysta, autor dzieła Die Diktatur (1921-1928). Nadto E. Fraenet, The Dual State. A Contribution to the Theory of Dictatorship (1941); G. Sartori, Appunti per una Teoria Generale della Diktatura (1971).

17 Jest to koncepcja C.J. Friedricha i Z K. Brzezińskiego, C.J. Friedrich i Z K. Brzeziński, Totalitarian Dictatorship and Autocracy, Harvard University Press 1956. 
syfikował dyktatury ze względu na stosowany przez nie reżim polityczny. Rozróżnił trzy ich rodzaje: autorytarną, totalitarną i pragmatyczną. Ta ostatnia pojmowana jest jako technokracja, najpierw dyktatura z lat Wielkiej Rewolucji Francuskiej, a później dyktatura profesjonalistów, głównie znawców techniki ${ }^{18}$.

Wiele sporów wywołała koncepcja dyktatury i jej usytuowania wobec autorytaryzmu i totalitaryzmu sformułowana przez Hannah Arendt. W ramach występującego w całych dziejach autorytaryzmu, utożsamianego przez tę myślicielkę z autokracją, tradycyjne autokracje - tyrania, despotyzm, absolutyzm - odróżniają się od autokracji współczesnych - militarnych (wojskowych) i jednopartyjnych (monopartyjnych). Natomiast totalitaryzm ograniczyła ona w czasie i przestrzeni do nazizmu niemieckiego lat 1938-1945 i stalinizmu sowieckiego z lat 1929-1941 i 1945-1953. To, co szczególnie sfrustrowało wielu komentatorów koncepcji Arendt, to wyodrębnienie przez nią dyktatury nietotalitarnej (nontotalitarian dictatorship), usiłujące uzasadnić „normalny” charakter leninowskiej dyktatury rewolucyjnej (revolutionary dictatorship) jako nie mającej cech totalitaryzmu. Według niej, totalitarne rządy Stalina i Hitlera doprowadziły do atomizacji podlegających im społeczeństw, natomiast Lenin, wprowadzając dyktaturę jednej klasy (one - party dictatorship), w gruncie rzeczy dyktaturę biurokracji partyjnej, miał na celu zespolenie wokół idei socjalistycznych klasy i narody bezideowych dotychczas społeczeństw. Dzięki temu, Arendt obdarzyła Lenina określeniem Wielki Dyktator (Great Dictator), pomijając czy też przemilczając chronologiczne poprzedzanie totalitaryzmu stalinowskiego przez leninowską jednopartyjną dyktaturę rewolucyjną. Według niektórych interpretacji, przejście od dyktatury rewolucyjnej do totalitaryzmu dokonało się na drodze dyktatury kontrrewolucyjnej ${ }^{19}$.

W świetle rozważań Arendt, dyktatura jest szerszym pojęciem zawierającym w sobie węższe pojęcia rodzajów dyktatur - jednopartyjnej, militarnej, totalitarnej. Omawiając reżimy autorytarne, miała ona na myśli głównie dyktatury, nie zaznaczając jednak wyraźnie, że nie wszystkie reżimy autorytarne są dyktaturami. Dyktatury jednopartyjne nie są, według niej, w pełni totalitarnymi reżimami. Totalitarność dyktatur jednopartyjnych jest negatywna, ponieważ nie jest w stanie przejąć pełni władzy instytucji nie będących partiami. Dyktatury jednopartyjne, sięgając po przemoc, drastycznie ograniczają wolność, gdy reżimy totalitarne dążąc do pełnej indoktrynacji w ten sposób znoszą wolność. Także sposób definiowania wroga odróżnia dyktatury jednopartyjne od totalitaryzmu. Dla dyktatury jednopartyjnej wrogiem jest ten, kto politycznie wyraźnie się jej sprzeciwia. W totalitaryzmie ten, kto nie jest z nami jest przeciwko nam i jest naszym wrogiem. Na gruncie totalitaryzmu, nawet członkowie elit panujących nie mogą czuć się bezpiecznie, w przeciwieństwie do dykta- 
tury jednopartyjnej. Terror dyktatury jednopartyjnej godzi w jej przeciwników, ale nie w obywateli, co występuje w totalitaryzmie.

Tak oto dyktatura jednopartyjna i totalitaryzm są traktowane przez Arendt jako dwa dość zasadniczo różne reżimy, mimo że totalitaryzm zawsze posiada cechy dyktatury. W związku z koncepcją Arendt i jej interpretacjami można rozróżnić dwa konteksty dyktatury - pozytywny rzymski jej sens historyczny i jej sens odrodzony po około osiemnastu stuleciach dla legitymizacji dyktatur rewolucyjnych. Te dwa konteksty stwarzają podstawę dla rozróżnienia trojakich dyktatur: rzymskiej, starożytnej, okresowej, nadzwyczajnej, wszechwładnego obrońcy instytucji republikańskich w międzyczasie wojny i rebelii (dictatura seditionis sedandae et rei gurundae causa); uzasadnionej ustanowieniem i odbudowaniem zrujnowanej rzeczywistości publicznej (dictator rei publicae constituendae); rewolucyjnej dyktatury jednopartyjnej. Wszystkie te trzy rodzaje dyktatury wymagają nadzwyczajnych prerogatyw dla dyktatorów, dotyczących obowiązywania prawa i istniejącego podziału władzy. Dyktatury jednoosobowe nazywane są dyktaturami suwerennymi, natomiast dyktatury małej grupy osób - dyktaturami komisarycznymi. Zatem można twierdzić, że totalitaryzm jest dyktaturą, ale nie każda dyktatura jest totalitaryzmem. Dla obrony demokracji uzasadnione jest sprzeciwienie się wszelkim dyktaturom, nawet tym, które usiłują wykazywać swój nietotalitarny charakter. Współcześnie za najlepszą legitymizację władzy uchodzi jej demokratyczność i legalizm, chociaż niektórzy dostrzegają cechy dyktatury w pewnych rządach demokracji przedstawicielskiej ${ }^{20}$.

Dyktatura jest pojęciem zbiorczym, obejmującym idee i reżimy polityczne o charakterze absolutystycznym, autorytarnym i totalitarnym. Dyktatorzy - jednostka lub mała grupa osób - odrzucają wybory, konstytucje, rywalizację polityczną jako źródło i legitymizację swojej władzy, podejmując arbitralne, niekontrolowane decyzje, wspierane przemocą, bez żadnej ograniczonej albo całkowicie eliminowanej ochrony praw i wolności obywateli. Nie znajdując zracjonalizowanej legitymizacji swojej władzy, chętnie sięgają po demagogiczne treści wiary, dogmatów, mitów i uprzedzeń w swoich walkach z opozycją i wrogami rzeczywistymi lub wyimaginowanymi. Zwykle zadowalają się samą władzą, nie uzasadnianą szerzej i głębiej jakąś określoną, np. totalitarystyczną ideologią; kontrolują struktury państwa, nie aspirując do pełni władzy nad samym społeczeństwem. Do ulubionych haseł dyktatorów należy podkreślanie potrzeby stabilizacji, ładu, porządku, bezpieczeństwa i wprowadzenia reform.

Dyktatura, jako reżim polityczny utworzony bez zgody i aprobaty ludu, jest przeciwieństwem demokracji, polegającej na takiej zgodzie i aprobacie. Gdy demokracja oczekuje na przyzwolenie ludu do rządzenia, dyktatura odrzuca potrzebę legitymizacji swej władzy. Oto inne cechy dyktatury ujęte w formie ich przeciwsta- 
wień cechom demokracji: niekonstytucyjność - konstytucyjność, jednopartyjność wielopartyjność, monizm polityczny - pluralizm polityczny, nieodpowiedzialność dyktatorów - odpowiedzialność rządzących, autokratyzm - heterokratyzm. Autokratyzm, jako cecha dyktatury, jest jeszcze bardziej kontrastowym pojęciem wobec demokracji niż dyktatura, toteż nazywany jest niekiedy niezbyt właściwie jako niedemokracja. Próbę pogodzenia dyktatury z demokracją usiłowano, bez powodzenia, rozwinąć i stosować w socjalistycznych państwach demokracji ludowej, opartych na dyktaturze proletariatu, czy też ludu pracującego miast i wsi. Zwolennicy dyktatury upatrują jedno z głównych jej uzasadnień w powolności i małej skuteczności władzy demokratycznej.

Spośród różnych rodzajów dyktatury, w najnowszych interpretacjach główną rolę spełniają trzy dyktatury - totalitarna, autorytarna i prosta. Rola ideologii jest największa, totalna, w dyktaturze totalitarnej, umiarkowana w dyktaturze autorytarnej i mało znacząca w dyktaturze prostej. Zniewolenie społeczeństwa obywatelskiego, intensywność przemocy i mobilizacji są największe w dyktaturze totalitarnej, średnie w dyktaturze autorytarnej i raczej niskie w dyktaturze prostej. W dyktaturze totalitarnej brak autonomii grup społecznych, w dyktaturze autorytarnej jest ona dozwolona dla grup apolitycznych, w dyktaturze prostej dozwolona, ale z wyjątkami. Dyktatura totalitarna działa destrukcyjnie na tworzenie grup społecznych, dyktatura autorytarna zapobiega ich tworzeniu, zaś dyktatura prosta stara się je wykorzystywać dla własnych celów. Arbitralność dyktatury totalitarnej jest nieograniczona, przewidywalna w dyktaturze autorytarnej, zmienna w dyktaturze prostej. Rola partii rządzącej w dyktaturze totalitarnej jest kluczowa, uznawana za pożyteczną w dyktaturze autorytarnej i minimalna, albo nawet żadna, w dyktaturze prostej ${ }^{21}$.

\section{Legitymizacja autorytaryzmu}

Pojęcie ,autorytaryzm” pochodzi od łacińskiego słowa autoritas, oznaczającego powagę, wpływ, znaczenie, władzę, autorytet. W myśli i praktyce politycznej funkcjonuje przede wszystkim w sensie ideologii, postawy psychicznej i niedemokratycznych rządów. Stworzone przez faszystów, uwikłane jest w związki z wieloma pojęciami, głównie jednak dyktatury i totalitaryzmu, toteż sprawia duże trudności przy jego wyjaśnianiu. Wydaje się, że w dochodzeniu do istoty autorytaryzmu najlepiej wyjść od pozytywnie ocenianego pojęcia autorytet, ponieważ autorytaryzm jest negatywnym przejawem nadużycia autorytetu w myśli i praktyce politycznej. Gdy autorytaryzm, który powinien być odróżniany od pozytywnego sensu autorytywizmu kojarzony jest zawsze zarówno z legitymizacją, jak i legalizacją - autorytaryzm nie troszczy się o legalizm i nie zawsze posiada dostateczną legitymizację. 
Autorytet, jako pojęcie, ma taki sam rodowód etymologiczny jak pojęcie autorytaryzm. Wyraża uznanie, zaufanie, wysoki prestiż, charyzmę, cechy prawdziwe - osób, grup społecznych, instytucji - oparte na przypisywanych im wysoko cenionych wartościach. W psychologii autorytetem są osoby, którym ulegają i podporządkowują się inne osoby. W pedagogice - są nimi wychowawcy i nauczyciele, imponujący wychowankom i uczniom dużą wiedzą i bogatymi doświadczeniami życiowymi. W naukach i praktykach politycznych posiadanie autorytetu dobrze służy legitymizacji władzy. Nierzadko, pozory autorytetu nadaje nawet tylko odpowiedni ubiór - toga, mundur, sutanna, elegancki garnitur, w którym może, ale nie musi, znajdować się autorytet rzeczywisty. Bez wątpienia, autorytet może pochodzić także z określonych tytułów, rang, stopni i dystynkcji ${ }^{22}$.

Największym zaufaniem cieszą się autorytety naukowe, ponieważ poddawane są niczym nieograniczonej sprawdzalności. Autorytety religijne, nie chcąc poddawać się podobnej sprawdzalności - weryfikacji czy też falsyfikacji głoszonych prawd objawionych i spisywanych w jakichś pismach świętych, przy pomocy dogmatów dekretują swoją nieomylność. Autorytety moralne to wzory osobowe i ich normy postępowania, ale tylko dla tych, którzy je wybrali wśród wielu takich wzorów i norm i aprobowali na swój użytek. Autorytety polityczne, najbardziej znaczące dla wyjaśniania pojęcia autorytaryzm, przejawiają się poprzez cechy wrodzone lub nabyte, umożliwiające uzyskiwanie władzy formalnej albo (i) faktycznej nad innymi i nagradzania ich posłuszeństwa albo karania nieposłuszeństwa. Osiąganiu wszystkich tych wspomnianych rodzajów autorytetu sprzyjać może charakter autorytarny, jako z jednej strony psychologiczna dyspozycja do narzucania swej woli innym, z drugiej zaś strony jako uległość takiej narzuconej woli. Autorytet powiązany najściślej z różnymi przejawami władzy, nie jest z nią jednak tożsamy, ponieważ istnieją zarówno władze posiadające autorytet, jak i pozbawione autorytetu.

W myśli politycznej autorytaryzm odrzuca anarchizm, liberalizm, demokratyzm i parlamentaryzm, ponieważ pochwala silną władzę wykonawczą autorytetu politycznego, wymusza konieczność bezwzględnej uległości podwładnych władzy państwowej, oczekuje szacunku i pochwał dla rządów wybitnych jednostek albo małych grup elitarnych. Z tego powodu, bliski jest zarówno myśli konserwatyzmu, wątpiącego w wartość wolności i tolerancji, jak i katolicyzmu w jego doktrynie społecznej Kościoła. Autorytaryzm zyskał od XIX wieku otwartą przychylność ze strony konserwatywnego Kościoła rzymskokatolickiego, jak wiadomo, szeroko posługującego się autorytaryzmem na swój własny użytek. Autorytaryzm nie troszczy się o proceduralne legitymizowanie podmiotów władzy autorytarnej. Kontentuje się samym jej posiadaniem, utrwalaniem i zwalczaniem opozycji, jeżeli już dopuścił do jej powstania, istnienia i przetrwania. Podmioty te, przeświadczone o swojej charyzmatycz- 
nej wyjątkowości i wielkości, niechętnie przyjmują albo nawet całkowicie odrzucają wszelką ich krytykę ${ }^{23}$.

Pojęcie autorytaryzmu, rozwijane w myśli politycznej, służy praktyce politycznej do wyjaśnienia cech reżimów politycznych, zwanych autorytarnymi. Chronologicznie reżim totalitarny powstał najpierw na Węgrzech w 1920 roku, następnie, do wybuchu II wojny światowej, w wielu krajach europejskich, a po tej wojnie w krajach Ameryki Łacińskiej, pokolonialnych krajach arabskich, Czarnej Afryki i Dalekiego Wschodu. Reżimy autorytarne opierają się na instytucjach zabezpieczających trwałość i niepodważalność autorytetu władzy. Do najbardziej skutecznych instytucji tego rodzaju należy policja polityczna, przejawiająca autorytaryzm policyjny i armia dysponująca autorytaryzmem militarnym. W krajach reżimu autorytarnego istnieje ograniczony pluralizm polityczny pod warunkiem, że nie ma on charakteru opozycji wobec pomiotów władzy. Ideologia wypierana tutaj przez cechy osobowości autorytarnej, nie odgrywa większej roli, podobnie jak formalnoprawne określenie zakresów i sposobów sprawowania władzy przez przywódcę albo oligarchiczną grupę. Wysoko oceniana jest sprawność aparatu władzy, zdolnej do neutralizowania opozycji, jak również pasywność polityczna społeczeństwa, pozbawionego możliwości wyboru władz i kontrolowanego przez cenzurę.

„Charakteryzując dziewiętnastowieczne formy autorytaryzmu, wypierające republikańskie, demokratyczne i pluralistyczne modele państwa na rzecz monarchicznych, centralistyczno-biurokratycznych i unitarnych, Ernest Nolte stwierdził, że autorytarną można nazwać każdą formę ustrojową, w której przyznaje się wyższą pozycję innemu składnikowi władzy naczelnej niż parlament. Takie ujęcie autorytaryzmu, wyłącznie przez pryzmat jego antyparlamentaryzmu, wydaje się zbyt ograniczone, dlatego też J. Linz, próbując zdefiniować interesujący nas rodzaj systemu, zwrócił uwagę także na inne elementy. Jego zdaniem, autorytarne reżimy są systemami politycznymi z ograniczonym, nie opartym na odpowiedzialności, pluralizmie politycznym, bez starannie wypracowanej, kierowniczej ideologii (ale o wyraźnej mentalności), bez intensywnej czy ekstensywnej mobilizacji politycznej (z wyjątkiem pewnych etapów ich rozwoju), w których przywódca (czasami mała grupa) pełni władzę w ramach formalnie słabo zdefiniowanych, ale w rzeczywistości dobrze przewidywalnych ograniczeń. Autor ten zastrzega, że typowe na ogół dla systemów autorytarnych przywództwo jednostkowe nie jest warunkiem koniecznym, gdyż możemy mieć do czynienia z instytucją junty lub innego kolektywnego ośrodka decyzji

23 Szerzej por. m. in. I. R. Simon, A General Theory of Authority, Notre Dame 1962; H. S. Kariel, In Search of Authority. Twentieth Century Political Thought, New York 1964; E. C. Page, Political Authority and Bureauoratic Power, Brighton 1985; A. Perlmutter, Modern Authoritarianisme. A Comparative Institutional Analysis, New Haven 1983; H. Arendt, Co to jest autorytet?, (w:) Między czasem minionym a przyszłym. Osiem ćwiczeń z myśli politycznej, Warszawa 1993. 
politycznej i osobowość przywódcy nie musi być czynnikiem określającym tożsamość systemu"24.

Do niemal bezdyskusyjnych cech wszystkich reżimów autorytarnych należy: uznawanie suwerenności własnego kraju za najwyższą wartość polityczną, wymagającą ideowego i konstytucyjnego potwierdzenia; opieranie polityki na treściach tradycyjnej moralności uzgodnionej z religią; aprobowanie silnej władzy jednostki lub małej grupy, jako piastunów interesów całego społeczeństwa, bez potrzeby funkcjonowania parlamentu; przekonanie, że więzy solidaryzmu społecznego odgrywają kluczową rolę, toteż należy odrzucać koncepcje eksponujące konflikty społeczne; poleganie na liberalnym modelu gospodarki rynkowej, jako materialnym fundamencie wszystkich przejawów polityki. Na tle tych cech odrzucony już został pogląd o autorytarnym charakterze państw tzw. realnego socjalizmu, ponieważ był ich diametralnym zaprzeczeniem. Państwa bowiem realnego socjalizmu: aprobowały swoją zależność od ZSRR; ukazywały politykę w świetle nowej moralności socjalistycznej; propagowały prymat interesów klasy panującej obwarowanych hegemonią jednej partii; uznawały walkę klas, a nie solidaryzm społeczny, za nieodłączną cechę społeczeństw przedkomunistycznych; dopatrywały się doskonałości w formach własności społecznej zarządzanej na zasadzie centralnego planowania ${ }^{25}$.

Wiedzę o autorytaryzmach wzbogacają ich klasyfikacje, w oparciu o krzyżujące się kryteria, wskazujące zarówno pewne przeciwstawności ich cech, jak i cech stanowisk pośrednich. Charakter ideologii pozwala rozróżniać autorytaryzmy prawicowe, umiarkowane i lewicowe. Ze względu na kryterium podmiotu władzy wyróżniane są autorytaryzmy: teokratyczne, gdy władza należy głównie do duchownych; monarchistyczne, gdy różnie nazywany jedynowładca sprawuje władzę autorytarną ${ }^{26}$; republikańskie, gdy władza z demokratycznego wyboru przeistacza się we władzę autorytarną; wojskowe, gdy władza należy do autorytarnych ze swej istoty wojskowych - elity, junty, grupy; cywilne, gdy władzę sprawują jednostki lub małe grupy, nie będące ani duchownymi, ani wojskowymi; biurokratyczne, gdy władza jest zdominowana przez technokratów; biurokratyczno-militarne, łączące cechy obu tych autorytaryzmów; państwowe, nacjonalistyczne, rasowe, etniczne, rodzinne. Ze względu na kryterium religijne, występują autorytaryzmy proreligijne, neutralne religijnie i antyreligijne. Ze względu na stosunek do aktywności politycznej obywateli, istnieją autorytaryzmy mobilizacyjne, postdemokratyczne i postkolonialne. Wreszcie, z uwagi na stosunek do totalitaryzmu - należy wymienić autorytaryzmy prototalitarne i posttotalitarne ${ }^{27}$.

W. Sokół, Autorytaryzm (w:) Mały Leksykon..., op. cit., s. 31 i nast.; Przede wszystkim jednak por. J.J. Linz, Authoritarian Regime: Spain, (w:) Mass Politics. Studies in Political Sociology, New York 1970.

25 Por. W.T. Kulesza, Fundamenty autorytetu, „Przegląd Tygodniowy” 1990, nr 50.

26 Oto niektóre nazwy jedynowładców, posiadających władzę autorytarną: monarcha, król, emir, szejk, caudillo, regent, protektor, kanclerz, premier, prezydent.

27 Por. szerzej B. Allemeyer, Right - Wing Authoritarianism, University of Monitoba Press 1981; idem, The Authoritarian Specter, Harvard University Press 1996; idem, The Authoritarians, Lulu 2006. 
W relacji do demokracji, autorytaryzm jest antydemokratyczny, ponieważ odrzuca jej główne instytucje i procedury - autonomię polityczną obywateli, wybory, partie polityczne, parlament, istnienie opozycji, tolerancję mniejszości. Autorytaryzm, jako reżim ponadparlamentarny, albo pozaparlamentarny, różni się w sposób zasadniczy od demokratyzmu wspierającego się na władzy parlamentu reprezentującego większość społeczeństwa. Tezę tę komplikuje nieco odróżnianie antydemokratyzmu od negatywnego antyparlamentaryzmu pełnego i pozytywnego antyparlamentaryzmu częściowego. Ten ostatni odrzuca wprawdzie reprezentację jednostek ludzkich w parlamencie, ale akceptuje reprezentację w nim grup społecznych - prowincji, stanów, rodzin, jak to miewało miejsce w parlamentach przedliberalnych ${ }^{28}$. Niemałe też zamieszanie pojęciowe powoduje przeistaczanie się demokratycznie wybranych władz w hybrydy reżimu demokratyczno-autorytarnego. Występuje to najczęściej, gdy dominujący polityk lub mała grupa polityków legitymizuje swoją autorytarną arbitralność rzekomym przyzwoleniem wyborców. Przeistoczenie takie staje się oczywiste zawsze po wprowadzeniu w dotychczasowej demokracji stanu wyjątkowego, tym bardziej stanu wojennego. Trzeba również mieć na uwadze, że niechęć obywateli wielu współczesnych krajów do uczestniczenia w procesach demokratycznych sprzyja autorytaryzmowi.

Autorytaryzm, w swym natężeniu przymusu i ograniczeń wolności obywateli, jest stopniowalny na jakiejś skali spektrum od demokracji, poprzez różne formy dyktatury, aż do totalitaryzmu. Istnieją formy reżimów politycznych, które: zawsze są autorytarne (despotie, dyktatury), niemal zawsze (teokracje, monarchie absolutne, autokracje militarne), często (państwa faszystowskie, państwa socjalistyczne z czasów stalinizmu) i tylko niekiedy (autorytarne demokracje). Zbyt rozległe i niedoprecyzowane w treści pojęcie autorytaryzm, w otoczce ubogiej jego ideologii, zastępowanej autorytarną mentalnością, zaciera możliwości wyraźnego podziału władz na demokratyczne i autorytarne. Rozległość owa i owe niedoprecyzowanie wynikają przede wszystkim z dość powszechnego przekonania, że wszelka władza może pretendować do autorytetu. Zawęża i precyzuje nieco pojęcie autorytaryzmu odróżnianie pozytywnego zawsze sensu autorytatywności, przynajmniej częściowo, zgodnej z demokratyzmem od negatywnego, na ogół, antydemokratycznego znaczenia autorytaryzmu. Powiązana ściśle z demokracją ,prawdziwa wolność akceptuje autorytet, tak jak prawdziwy autorytet uznaje potrzebę wolności... autorytet, który nie rozwija wolności jest autorytaryzmem"29.

Każdy autorytaryzm jest, w mniejszym lub większym stopniu, dyktaturą, jednakże dyktatury totalitarne są już skrajną odmianą dyktatury, a więc już czymś większym niż autorytaryzm. Rysują się zatem dość zasadnicze różnice między autorytaryzmem a totalitaryzmem. Po pierwsze, reżimy autorytarne posługują się insty- 
tucjami i instytucjonalizacją ograniczonego pluralizmu, gdy reżimy totalitarne mają zdecydowanie antyinstytucjonalny, monopolistyczny charakter. Po drugie, reżimy autorytarne osłabiają albo nawet eliminują mobilizację społeczną, lekceważąc ideologię, gdy reżimy totalitarne są ruchami opartymi na skrajnie zideologizowanej mobilizacji. Po trzecie, autorytaryzm zachowuje represyjne prawo, gdy reżimy totalitarne doprowadzają do nihilizmu prawnego. Po czwarte, pragmatycznym reżimom autorytarnym może dobrze służyć sprawnie funkcjonujące państwo, gdy reżimy totalitarne arbitralnością przywódcy, predominacją partii, militaryzacją i skrajną ideologizacją dezorganizują państwo. Po piąte, w reżimach autorytarnych centrum władzy może pozostawać w ręku jednostki albo małej grupy, gdy w reżimach totalitarnych należy do jednostki - przywódcy, duce, führera; jednak oba reżimy ubiegają się o charyzmę dla swej władzy. Po szóste, reżimy autorytarne, mimo że represjonują swoich politycznych oponentów, pozostawiają jednak większe zakresy dla prywatności obywateli niż zmierzające do całkowitego jej unicestwiania reżimy totalitarne posługujące się kontrolowaniem i inwigilacją. Błędne jest przeto utożsamianie autorytaryzmu z totalitaryzmem, mimo że ten drugi może odznaczać się niektórymi cechami tego pierwszego ${ }^{30}$.

\section{Legitymizacja totalitaryzmu}

Nazwa „totalitaryzm” pochodzi od łacińskiego słowa totus albo totalis - cały, całkowity, wszystek, obejmujący wszystkie dziedziny, występującego w języku włoskim jako totalitario ${ }^{31}$. Właśnie we Włoszech rozpoczyna się szerokie stosowanie tej nazwy dla określenia ideologii, przywódców, partii i ruchów politycznych oraz państw. Stało się to w 1922 roku, gdy Benito Mussolini ogłosił koncepcję państwa totalitarnego (stato totalitario). Koncepcja została oparta na haśle „Nic przeciw państwu, nic poza państwem, nic bez państwa”. Rozwinęli ją szerzej główni ideologowie faszyzmu włoskiego Benito Mussolini i Giovanni Gentile w książce Origini e dottrina del fascismo (1932). Od tego czasu, najogólniejszy sens pojęcia totalitaryzm wyrażają totalistyczne i absolutystyczne idee i praktyki w pełni scentralizowanego reżimu politycznego, sprawującego całkowitą kontrolę nad państwem i społeczeństwem, określanego inaczej najczęściej dyktaturą albo autorytaryzmem, rzadziej zaś monokracją, jedynowładztwem, despotyzmem i tylko już niekiedy tyranią.

Jeśli przyjęlibyśmy, że najważniejszą cechą totalitaryzmu jest w pełni scentralizowany reżim polityczny, to jego pierwsze przykłady datowane są na bardzo za-

Tak trafnie J.J. Linz, Totalitarian..., op. cit., także J.J. Linz, A. Stepan, Problems of Democratic Transition and Consolidation, Baltimore 1996; W. Fowler (ed.), Authoritarianism in Latin America since Indenpendence, Westport 1996.

31 Nazwa „totalitaryzm” niekiedy używana jest zamiennie z nazwą „totalizm”, w krajach socjalistycznych odnoszoną głównie do faszyzmu. W innych krajach, a później i w krajach postsocjalistycznych używana jest nazwa „totalitaryzm". W języku angielskim słowo totalitarian pojawiło się w 1926 roku. Tak przynajmniej twierdzi E. Kamenka, Totalitaryzm, (w:) Przewodnik po współczesnej filozofii politycznej, Warszawa 1998, s. 800. 
mierzchłe czasy: panowania dynastii Maurya w Indiach (321-185 r. p.n.e.), chińskiej dynastii China (221-206 r. p.n.e.), rządów Shaka u Zulusów (1816-1828). Totalitaryzm kojarzony jest jednak ze współczesnymi, skrajnie scentralizowanymi reżimami XX wieku - Niemiec pod rządami Adolfa Hitlera (1933-1945) i Związku Radzieckiego z okresu panowania Józefa Stalina (1924-1953). Przytoczone przykłady dotyczą totalitarnych praktyk politycznych, natomiast źródła ideologii totalitaryzmu wciąż pozostają jeszcze w kręgu sporów. Gdy jedni badacze dopatrują się pierwszych pomysłów totalitaryzmu już w starożytnej filozofii politycznej Platona i dostrzegają jej kontynuatorów w Machiavellim, Rousseau, Heglu i Marksie, inni twierdzą, że myśl totalitaryzmu należy wyłącznie do XX wieku ${ }^{32}$.

Dla włoskich twórców pojęcia totalitaryzm miało ono, oczywiście, znaczenie bardzo pozytywne. Jednakże, już podczas II wojny światowej pojęcie to nabrało zdecydowanie negatywnego sensu, używanego dla krytyki totalistycznych reżimów i społeczeństw Niemiec nazistowskich i stalinowskiego Związku Radzieckiego $^{33}$. W okresie powojennym, gdy dociekano źródeł totalitaryzmu, pojęcie to nabrało nowego wigoru, głównie dzięki publikacji dzieła Hannah Arend The Origins of Totalitarianism (1951). W okresie tzw. zimnej wojny pojęcie to spopularyzowali w kręgach akademickich i politycznych świata dwaj politolodzy amerykańscy - Carl Friedrich i Zbigniew Brzeziński. Mniej natomiast znany jest interesujący wkład do charakterystyki istoty totalitaryzmu wniesiony przez amerykańskiego znawcę ruchów masowych Erica Hoffera ${ }^{34}$.

Dzieło Hannah Arendt, Żydówki niemieckiej, która z obawy przed nazizmem wyemigrowała do Stanów Zjednoczonych, zostało dedykowane jej mężowi Heinrichowi. W gruncie rzeczy jednak jest ono dedykowane wszystkim Żydom, doświadczającym skutków antysemityzmu od połowy XIX wieku aż do wielkiej ich zagłady podczas II wojny światowej. Arendt, poszukując źródeł totalitaryzmu, dostrzegła je w rozwoju rasizmu, jako ,ideologicznej broni imperializmu” nacjonalistycznych państw, owładniętych pangermanizmem i panislamizmem, w ich militarystycznych dążeniach do rozszerzenia granic swych państw, a nawet panowania nad światem. Doszła przy tym do zaskakującego wniosku, że gdy faszyzm włoski pozostawał autorytarnym ruchem nacjonalistycznym, gloryfikującym państwo, to nazizm niemiecki upodobnił się do wcześniejszego stalinizmu sowieckiego, ponieważ oba były ruchami totalitarystycznymi, rujnującymi struktury państwowe. W konkluzjach swoich wywodów, myślicielka opisała i oceniła instytucje i działania ruchów totalitar-

32

Ten drugi pogląd, bardziej uzasadniony, rozwinęła grupa najbardziej znanych badaczy totalitaryzmu: Hannah Arendt, Carl J. Friedrich i Z. Brzeziński.

Pierwszeństwo w tym względzie przypisywane jest Isabel Paterson, The God of the Machine (1943) i Karlowi Popperowi, The Open Society and Its Enemies (1945), który w tym, i następnym swym dziele The Poverty of Historicism (1961), przeciwstawił totalitaryzmowi koncepcję otwartego społeczeństwa liberalnej demokracji.

Do najnowszych interpretacji totalitaryzmu należą m.in.: S.P. Soper, Totalitarianism: A Conceptual Approach, London 1985; A, Gleason, Totalitarianism, New York and Oxford 1995; S. Zizek; Did Somebody Say Totalitarianism? London 2001; E. Murray, Shut Up: Tale of Totalitarianism, 2005. 
nych. Podkreśliła, że idee, formy rządów totalitarnych istniały jedynie w pierwszej połowie XX wieku, w nazistowskich Niemczech i stalinowskiej Rosji. W związku z tymi rządami, omówiła przeobrażenie się klas społecznych w masy społeczne, zniszczenie granic oddzielających państwo od społeczeństwa skrajnym jego upolitycznieniem, rolę propagandy w oddziaływaniu na świat nietotalitarny, nadużywanie terroru. Oceniła te cechy jako najbardziej istotne dla form reżimu totalitarnego. Do drugiego wydania swego dzieła z 1958 roku Arendt dodała jeszcze analizę sensu izolacji jednostki ludzkiej i samotności człowieka, nie odróżniającego prawdy od fałszu w polityce, jako prewarunków ukształtowania się totalnej dominacji ${ }^{35}$.

Charakterystyka totalitaryzmu, opracowana przez Arendt, została rozwinięta, pogłębiona i uporządkowana w koncepcji syndromu totalitaryzmu złożonego z sześciu składników, zawartej w dziele C. J. Friedricha i Z. Brzezińskiego, Totalitarian Dictatorship and Autocracy (1956). Są to następujące składniki: totalitarna ideologia; jedna masowa partia, w zasadzie pod jednoosobowym kierownictwem, podporządkowująca sobie biurokrację rządową; terror fizyczny i psychiczny, stosowany przez partię środkami ideologicznymi i tajnej policji, skierowanymi przeciwko jawnym wrogom reżimu i arbitralnie wskazywanym grupom ludności; wyłączność kontrolowania wszystkich środków masowego przekazu, takich zwłaszcza jak prasa, radio, film; monopol przywódcy na podporządkowanie sił zbrojnych przygotowywanych do agresji; kontrolowanie wszystkich organizacji, szczególnie zarządzania gospodarką, poprzez centralne planowanie. Jeśli trzy ostatnie składniki zostałyby zredukowane do pojęcia monopolu - medialnego, militarnego i kontrolowania - możnaby było mówić o syndromie trzech składników totalitaryzmu. W każdym jednak razie, do niezbędnych składników totalitaryzmu należą: monistyczna, niekoniecznie monolityczna, władza centralna, jedna, oficjalna, autonomiczna, mniej lub bardziej, zracjonalizowana ideologia, narzucana masom przez przywódcę partii, mobilizacja społeczeństwa do realizacji celów arbitralnie wskazywanych przez przywódcę ${ }^{36}$.

Eric Hoffer, uznawany przez faszystów amerykańskich za ich ideologa, nawiązując do sporów na temat założeń z jednej strony demokratyzmu, z drugiej zaś totalitaryzmu, wyraził swoje wątpliwości dotyczące prawdziwości myśli liberalizmu. Pytał: „Jeśli ludzie są racjonalni, liczą głównie na własne siły i kochają wolność - jak utrzymuje liberalizm - to dlaczego przyjmują dyktaturę i ciążą ku ruchom masowym? Gdyby sformułowania liberalizmu były prawdziwe, fakty nie mogłyby mieć miejsca..." W związku z tym Hoffer odchodzi od liberalizmu w trzech zasadniczych punktach. W pierwszym podważa przekonanie o indywidualnym dążeniu ludzi do zaspokojenia własnych interesów materialnych. Jego zdaniem, ludzie zmie-

\footnotetext{
35 Analizę tę zawiera już wydanie polskie dzieła H. Arendt, Korzenie totalitaryzmu, Warszawa 1989. Znajduje się ono w rankingach 100 i 50 najlepszych książek spoza literatury pięknej XX wieku.

36 Jest to propozycja, którą sformułował hiszpański politolog J. Linz, Totalitaryzm i autorytaryzm, (w:) Władza i społeczeństwo, wybór i opracowanie J. Szczupaczyński, Warszawa 1995, s. 303.
} 
rzają przede wszystkim do osobistego bezpieczeństwa, znajdując je w ruchach masowych. W drugim punkcie zaprzecza tezie o powszechnym umiłowaniu wolności, wskazując, ,że sfrustrowani ludzie naszych czasów pragną raczej «ucieczki od wolności»". W trzecim punkcie kwestionuje założenie o racjonalnym działaniu ludzi, dowodząc, że większość ich dokonań opiera się na odruchach emocjonalnych" ${ }^{37}$.

Zróżnicowane interpretacje pojęcia totalitaryzm sugerują, że nie może ono być jakimś jednolitym modelem ideologicznym, ani też jednakową praktyką reżimów politycznych. Pozostaje raczej jako ideologiczne spektrum zróżnicowanych zakresów i intensywności reżimowej totalności. $Z$ tego względu, podatny jest na niewłaściwe posługiwanie się nim przez nadużywających go demagogów. Pojęcie totalitaryzm, jeśli jest właściwie rozumiane, okazuje się jednak niezbędne ,ponieważ przypomina nam ono bowiem o istnieniu etapów w dziejach narodów (być może każdego narodu), kiedy fanatyzm, arogancja, bezwzględność i pycha jednostki, mogą wtrącić miliony mężczyzn i kobiet w otchłań szaleństwa, cierpienia, strachu i destrukcji”38. Bez wątpienia, podłożem ideologicznym totalitaryzmu faszystowskiego był przede wszystkim skrajnie szowinistyczny nacjonalizm, w totalitaryzmie stalinowskim natomiast, chyba, idee zaostrzającej się walki klas i nieuchronności konfliktów państw socjalistycznych z państwami kapitalistycznymi ${ }^{39}$. W praktyce totalitarystycznych reżimów politycznych panowała przemoc masowego terroru przywódców, posługujących się partią, ideologią, mediami, policją, wojskiem. Mobilizowano masy do czynnego udziału w realizacji narzucanych im odgórnie celów, w warunkach zacierania się granic między społeczeństwem a państwem.

Pojęcie totalitaryzm staje się zapewne bardziej wyraziste po komparatystycznym zestawieniu go z pojęciami demokracja, dyktatura i autorytaryzm ${ }^{40}$.

W powierzchownych interpretacjach pogardzonego pojęcia totalitaryzm, poprzestaje się nierzadko na lakonicznym stwierdzeniu, że jest ono całkowitym i prostym przeciwieństwem, pochwalanej zwykle, ideologii liberalizmu i praktyki politycznej ustrojów demokratycznych. Pogłębiona analiza totalitaryzmu prowadzi jednak do innego wniosku. Oto, skoro pretenduje on do obejmowania wszystkiego, co publiczne, to jego przeciwieństwem może być tylko prywatność i całkowicie bierne, nieinterweniujące państwo. Nie jest nim natomiast praktyka polityczna ustrojów demokratycznych, obejmujących zasięgiem swojego interwencjonizmu coraz to nowe sfery życia. Trafnie przeto zauważa Sartori, że demokratyczne państwo, co paradoksalne, ale prawdziwe, ma większą legitymizację polityczną i prawną do

R. Tokarczyk, Współczesna amerykańska myśl polityczna, Warszawa 1981, s. 188. Główna publikacja E. Hoffera nosi tytuł The True Beliver. Thoughts on the Nature Mass, Movements b.m. wyd. 1951.

38 L.B. Shapiro, Totalitarianism, London 1972, s. 125.

39 Na tym tle bardzo mdły i nieprzekonywujący jest pogląd, że głównym źródłem totalitaryzmu jest resentyment, który opublikował R. Sruton, Źródło totalitaryzmu, Ośrodek Myśli Politycznej 2005, tekst dostępny na stronach Internetu.

40 Komparatystyce tego rodzaju przydatna jest książka K.A. Wiffogel, Oriental Despotism: A Comparative Study of Total Power, New Haven 1957. 
stawania się obejmującym wszystko państwem totalitarnym niż państwa niedemokratyczne $^{41}$. Wynika z tego wniosek, że istoty totalitaryzmu należy poszukiwać nie w rozszerzaniu zasięgu interwencjonizmu państwowego, lecz raczej w autorytarnym lub (i) absolutystycznym posługiwaniu się władzą. Należy przy tym zauważyć, że każdy reżim totalitarny jest równocześnie autorytarny, albo (i) absolutystyczny, ale nie odwrotnie. Nadto trzeba dodać, że w pojęciu absolutyzm wyczuwa się większe natężenie władztwa niż w pojęciu autorytaryzm. Przeto, pojęcie absolutyzm bliższe jest pojęciu totalitaryzm niż pojęcie autokratyzm ${ }^{42}$. W spektrum zróżnicowanych treści, prowadzących od pojęcia demokracja do pojęcia totalitaryzm, mieści się, od tego pierwszego ku temu drugiemu, rozległa sfera słabnięcia demokracji i narastania totalitaryzmu, zaś od tego drugiego ku temu pierwszemu - wręcz odwrotnie.

Gdyby został przyjęty, bez zastrzeżeń, dość powierzchowny pogląd, że totalitaryzm jest wyłącznie formą dyktatury doprowadzonej do skrajności, należałoby zrezygnować z pojęcia totalitaryzm. Dostrzegając jednak uzasadnioną potrzebę zachowania przydatnego myśli i praktyce politycznej pojęcia totalitaryzm, należy podejmować trud odróżniania go nie tylko od pojęcia dyktatura, ale i pojęcia autorytaryzm. Jeśli dyktatura była ongiś utożsamiana z despotyzmem, sugestywnie brzmią słowa G. Orwella, że ,zasadą dawnego despotyzmu było «nie wolno»”. Zasadą totalitaryzmu jest «musisz»". Według poszukującego kompromisu poglądu cytowanego już Linza, totalitaryzm jest nową formą rządów, którą można jednak umieścić w ogólnej klasyfikacji rządów dyktatorskich. Jego zdaniem, istnieją dyktatury totalitarne i dyktatury nietotalitarne, czyli w gruncie rzeczy - autorytarne, gdy władza nie jest sprawowana w imię ideologii ${ }^{43}$. Jak natomiast zauważył Sartori, dyktatury totalitarne łatwiej rozwiązują problem sukcesji władzy niż dyktatury autorytarne. Te pierwsze dążą nadto do zniszczenia wszystkich podsystemów państwa, albo przynajmniej całkowitego ich podporządkowania dyktaturze przywódcy i jednej partii, gdy te drugie poprzestają na ich osłabianiu i separowaniu ${ }^{44}$. Totalitaryzm usiłuje oficjalnie uzasadniać demagogiczną ideologię, obwarowaną zakazami jej kwestionowania, projekty ukształtowania nowego wzoru człowieka i przebudowy całego świata. W odróżnieniu od tego autorytaryzm lekceważy potrzebę uzasadniania swej władzy, szczególnie przy pomocy ideologii. Oba te rodzaje dyktatur różnią jednak

41 G. Sartori, Teoria demokracji, op. cit., s. 238 i n. Interpretację tę powtórzył, nieco pretensjonalnie, ale jednak, K. Minoque, Co stanowi przeciwieństwo totalitaryzmu? Ośrodek Myśli Politycznej 2005, tekst na stronach Internetu.

42 Nazwa „absolutyzm” pochodzi od łacińskiego słowa absolutus, oznaczającego w odniesieniu do władzy jej koncentrację, centralizację i ponadprawność. Tak np. Słownik polityki, M. Bankowicz (red.), Warszawa 1996, s. 284.

43 J. Linz, Authoritarian..., op. cit., s. 303. Wszystkie dyktatury, zwłaszcza totalitarne, charakteryzuje polityczna hipokryzja, tyle, że w totalitaryzmie nazizmu ostentacyjnie jawna, zaś w stalinizmie nieudolnie ukrywana.

44 Curzio Malaparte, pisarz włoski, komentując pół żartem, pół serio znaną mu dobrze rolę prawa w faszyzmie włoskim, zauważył, że jest to reżim, w którym wszystko to, co nie jest zakazane jest obowiązkowe. Jest to przeciwieństwo Deklaracji Praw Człowieka, głoszącej w art. 5 zasadę „Co nie zakazane przez prawo, jest dozwolone”. Por. J. Baszkiewicz, Władza, Wrocław 1999, s. 149. 
przede wszystkim zakresy i głębsze oddziaływania reżimu politycznego na społeczeństwo i struktury państwowe ${ }^{45}$.

Po odróżnieniu dyktatur totalitarnych od dyktatur autorytarnych, niewiele już chyba można dodać na temat relacji totalitaryzmu i autorytaryzmu. Trzeba wszakże zauważyć, że w odróżnieniu od rządów demokratycznych i niektórych łagodnych rządów autorytarnych, mówi się bądź o surowych reżimach autorytarnych, bądź reżimach totalitarnych. W totalitaryzmie wykluczane są wszelkie przejawy pluralizmu, tolerowanego jednak, w mniejszych lub szerszych zakresach, w autorytaryzmie. Reżimy totalitarne mobilizują masy do identyfikacji intelektualnej i emocjonalnej z celami przywódcy i partii, natomiast rządy i reżimy autorytarne, kontentując się głównie samym sprawowaniem władzy, cenią sobie wysoko ideologiczną i polityczną bierność zdemobilizowanych mas. W autorytaryzmie niemal zawsze pozycja także przecież autorytatywnego Kościoła bywała znacząca, natomiast w totalitaryzmie była dość zróżnicowana. Faszyści włoscy działali w mniej lub bardziej jawnej zgodności z Kościołem ${ }^{46}$, naziści niemieccy lekceważyli tego rodzaju związki, natomiast totalitaryści stalinowscy metodycznie wyniszczali Kościół. Zgodnie ze spektrum typologii reżimów autorytarnych, zaproponowanej przez Juana Linza, droga prowadzi od reżimów prototalitarnych (faszyzm włoski), totalitarnych (nazizm niemiecki, totalitaryzm stalinowski), posttotalitarnych (społeczeństwa pod dominacją jednej partii) poprzez surowe reżimy biurokratyczno-militarne do łagodnych reżimów autorytarnych ${ }^{47}$. Typologia ta odsłania pewną różnicę między reżimami dyktatorskimi a reżimami autorytarnymi, w kontekście ich relacji z reżimami totalitarnymi. Otóż, gdy każdy reżim totalitarny jest jednocześnie dyktaturą i autorytaryzmem, to tylko niektóre reżimy dyktatorskie są reżimami totalitarnymi, chociaż wszystkie są autorytaryzmem. Nie są totalitarne liczne reżimy autorytarne, chociaż niektóre z nich bywają dyktaturami. Tak więc, zakres pojęcia autorytaryzm jest najszerszy, węższy jest zakres pojęcia dyktatura i najwęższy zakres pojęcia totalitaryzm ${ }^{48}$.

Totalitaryzm i jego interpretacje, głównie ze względu na nowatorstwo idei i tragiczne skutki jego praktyk, nie mógł nie wzbudzić dużego zainteresowania i zmasowanej krytyki. Oto np. dziełu Arend zarzucano przecenianie znaczenia antysemityzmu, wskazując, że nie odgrywał on głównej roli w żadnej formie totalita-

45 G. Sartori, Teoria demokracji, op. cit., s. 228 i n.

46 Jednakże należy zauważyć, że już w encyklice Piusa XI Quadragesimo anno z 1931 roku pojawił się papieski sprzeciw wobec narastającej omnipotencji włoskiego państwa faszystowskiego.

47 Typologia ta została oparta na wielu, krzyżujących się niekiedy, kryteriach osłabiających jej klarowność. Są to kryteria: stopnia i typu uczestnictwa (mobilizacji, zorganizowania, pluralizmu, kontrolowania, elitarności, apatii, odpolitycznienia), dominacji jednej partii korporacyjnej organizacji interesów, biurokratyczności technokratycznej, wojskowości - biurokratycznej mentalności, ideologizacji, J. Linz, Authoritarian..., op. cit., s. 320 i n.

48 Według doktryny Kirkpatrica, doradcy amerykańskiego ambasadora przy Organizacji Narodów Zjednoczonych i współtwórcy polityki zagranicznej prezydenta Ronalda Regana, na użytek Stanów Zjednoczonych, należy odróżniać typowe reżimy autorytarne, zintegrowane głównie swoim własnym przetrwaniem, od agresywnych reżimów totalitarnych, mogących szkodzić również interesom amerykańskim. Szerzej J. Kirkpatrick, Dictatorship and Double Standards, Rationalism and Reason in Pollitics, 1982. 
ryzmu. Natomiast poglądowi Friedricha i Brzezińskiego przeciwstawiano pogląd, że stalinowski reżim sowiecki należałoby raczej wyjaśniać w terminach nomenklatury - interesów nowych grup, elit, biurokracji, czy też nowych klas, a nie totalitaryzmu. Dodawano, że ich pogląd służył przede wszystkim dezinterpretacjom ideologicznym w okresie tzw. zimnej wojny, znamiennej ostrymi konfrontacjami państw socjalistycznych z państwami kapitalistycznymi. Pojęcie „,posttotalitaryzm”, wprowadzone przez Juana Linza okazało się zbyt statyczne w odniesieniu do samoreformujących się państw socjalistycznych, aż po ich upadek. Slavoj Zizek, filozof słowacki, w związku z tym twierdzi, że używanie koncepcji totalitaryzmu na użytek polityki ma jedynie, i to dość słabe, uzasadnienie ideologiczne, jako ,poskramiacza swobody radykałów" (tame of free radicals). Innymi słowy, jego zdaniem, te procesy polityczne, które nie mogą być wyjaśnione lub zrozumiane zgodnie z logiką liberalnej demokracji, zbyt pochopnie oznaczane są etykietką totalitaryzmu ${ }^{49}$. Ostatnio pojawiają się także próby porównywania globalnego społeczeństwa obywatelskiego (Global Civil Society) z totalitaryzmem ${ }^{50}$ i nazywania nowym totalitaryzmem (new totalitarianism) hegemonii cybernetyki w systemie globalnym ${ }^{51}$. Odrębny zaś nurt licznych już publikacji pod hasłem New Totalitarianism tworzy ostra krytyka polityki zagranicznej Stanów Zjednoczonych Ameryki, określonych w nich światowym Państwem Policyjnym (World Police State). Ten nowy totalitaryzm amerykański ma się wspierać na zasadzie „barbarzyńskiego wyniszczenia” wszystkich tych, którzy jako rzekomi wrogowie nie służą interesom tego kraju ${ }^{52}$.

\section{Najważniejsze wnioski}

Początek XXI wieku może skłaniać do ocen wieku poprzedniego, dla myśli i praktyki politycznej znamiennego przede wszystkim z powodu niespotykanego wcześniej nasilenia konfrontacji demokracji z jej zaprzeczeniem - dyktaturą, autorytaryzmem i totalitaryzmem. W poszukiwaniu wyjaśnień, nowemu spojrzeniu sprzyjają nowe okoliczności polityczne - z jednej strony upadek systemów państwowych zwanych totalitarnymi, z drugiej zaś strony pojawianie się w niektórych systemach państwowych, mieniących się formalnie demokratycznymi, cech właściwych dyktaturze, autorytaryzmowi, a także totalitaryzmowi.

Nawet ogólny przegląd treści pojęć demokracja, dyktatura, autorytaryzm, totalitaryzm, dzięki ich komparatystyce, prowadzi do wielu wniosków. Przede wszystkim, jest to wniosek, że główne i pierwotne znaczenie dla określania sensu wszystkich

49 S. Zizek, Did Somebody Say Totalitarianism, London 2001.

50 Tak np. C. Lucas, Global Civil Society v. Totalitarianism, tekst na stronach Internetu.

51 Por. szerzej W. Dan Perdue, The New Totalitarianism: Cyber hegomony and the Global System, tekst na stronach Internetu http://www.i-p-o.org/perdue.htm (data dostępu: 10.06.2015 r.).

52 Szczególnie pogłębiony, uzasadniony i sugestywny treścią i ilustracjami jest tekst The New Totalitarianism, jeszcze dostępny na stronach Internetu, gdy opracowywałem niniejszy tekst http://www.i-p-o.org/perdue.htm (data dostępu: 10.06.2015 r.). 
tych pojęć ma ich znaczenie etymologiczne, wywodzące się najczęściej od nazw i terminów znanych językowi greckiemu i językowi łacińskiemu już w starożytności. Nazwy te zostały przejęte przez inne języki niemal w dosłownym ich brzmieniu, albo z niewielkimi modyfikacjami, pod wpływem języków lokalnych, dla rozważań teoretycznych i celów praktyk politycznych.

Dla legitymizacyjnego opisywania i oceniania teoretycznych i praktycznych stron wszelkich fenomenów politycznych, szczególnie zaś takich jak demokracja, dyktatura, autorytaryzm, totalitaryzm decydujące znaczenie ma wybór ich nazwy jako szczególnego rodzaju etykietki, budzącej skojarzenia pozytywne albo negatywne. Na skali jakiegoś wyobrażanego, ale w rzeczywistości nieistniejącego obiektywnie, lecz tylko subiektywnie, spektrum ocennego od pozytywności do negatywności, szlaki niepogłębionej myśli i praktyki politycznej prowadzą od demokracji, poprzez autokratyzm, dyktaturę do totalitaryzmu. Pogłębianie wiedzy o treści tych pojęć komplikuje jednakże ten uproszczony pogląd, nie tylko dlatego, że z powodu sprzeczności politycznych to, co dla jednej strony jest pozytywne, dla drugiej strony bywa negatywne.

Istnieją przeto zarówno zwolennicy, jak i przeciwnicy demokracji, autorytaryzmu, dyktatury i totalitaryzmu. O ile w myśli politycznej, ze swej istoty abstrakcyjnej, można jeszcze usiłować poszukiwać jakichś powszechnie akceptowalnych, modelowanych treści interesujących nas pojęć, w praktyce politycznej, jak dotychczas, jest to zupełnie niemożliwe. W praktyce politycznej bowiem różne strony konfliktów politycznych ten sam fenomen polityczny określają różnymi nazwami, albo przynajmniej nadają tym samym nazwom różną treść. Powszechna prawomocność analizowanych pojęć byłaby możliwa dopiero wówczas, gdyby wszyscy, zgodnie, posługiwali się nie tylko pojęciami o takich samych nazwach, ale i takiej samej treści. Jak daleko jednak, niestety, do takiej zgodności niechże wskażą na to raz jeszcze kameleonowe oblicza rozważanych tutaj pojęć, skomplikowane pokrywanie i krzyżowanie się ich treściowych zakresów.

Wszystkie te pojęcia, służąc głównie legitymizacyjnemu opisywaniu i ocenianiu władzy, mają rozległe zakresy treściowe i ocenne, wykluczające wręcz zgodność poglądów teoretycznych, tym bardziej stanowisk praktycznych. Oto, demokracja, oceniana pozytywnie, ale tylko przez jej zwolenników, rozciąga swoje granice od demokracji ogółu - powszechnej, uczestnictwa, partycypacji - do demokracji przedstawicielskiej. Ale już między samymi zwolennikami jednej z tych koncepcji demokracji rysują się rozbieżności ocen. Jeżeli demokracja ogółu opiera się na posiadaniu całej władzy przez ogół jej podmiotów, może to, w karykaturalny wręcz sposób, potęgować wrażenie istnienia totalitaryzmu. Jeśli demokracja przedstawicielska dość łatwo może się przeradzać w autorytaryzm, albo nawet dyktaturę, wcześniej demokratycznie wybranych przedstawicieli, czym zatem, poza samym źródłem władzy, różni się ona od autorytaryzmu albo dyktatury. Jeżeli pełnia autorytaryzmu przejawia się równocześnie w pełni dyktatury, a pełnia dyktatury, równocześnie, w pełni 
totalitaryzmu, pojęcia te tracą swój odrębny sens; służą przede wszystkim i nierzadko jedynie za etykietki w konfrontacjach ideologicznych i politologicznych.

Nasuwa się przeto nieodparcie pytanie, czy należałoby dążyć do ograniczenia liczby pojęć nawet do jednego, jak np. autorytaryzm, przy pomocy którego możnaby było charakteryzować wszystkie przejawy myśli i praktyki politycznej w określonych ich zakresach. Dążenie takie byłoby chyba jednak uzasadnione tylko do pewnego stopnia dlatego, że każde z interesujących nas pojęć posiadać może niektóre cechy każdego innego, dominujące w pewnych koncepcjach, czy też okolicznościach, nad innymi. Demokracja, w zasadzie, może odznaczać się często cechami autorytaryzmu, niekiedy dyktatury, a nawet, wyjątkowo, totalitaryzmu. Autorytaryzm, niemal zawsze, cechuje demokrację, dyktaturę, jak również totalitaryzm w ocenach jego zwolenników. Dyktatura może wynikać z przeobrażeń demokracji, zawsze o cechach autorytaryzmu, osiągającego skrajność dyktatury totalitarnej. Wreszcie totalizm, w sensie osiągania jakiejś pełni, trudnej do odróżnienia od totalitaryzmu, pozytywnie ocenianej przez zwolenników, może być totalizmem - demokracji, autokratyzmu, dyktatury.

Wydaje się, że w zakresie komparatystyki relacji wzajemnych pojęć demokracji, autorytaryzmu, dyktatury i totalitaryzmu, pomocna może być wiedza dotycząca ekstremizmu politycznego. „W czasach uznawanych za współczesne ekstremizm polityczny sięgał skrajności ekstremizmu w dwóch formach totalitaryzmu - stalinowskiego i hitlerowskiego. Obaj dziejowi superekstremiści polityczni - Stalin i Hitler - potrafili zaprząc naukę, technikę i przede wszystkim siły milionów ludzi jako środki dla szaleńczych, wręcz obłędnych, ekstremistycznych celów. Chodziłoby szczególnie o pogłębioną komparatystykę ekstremizmu lewicowego i ekstremizmu prawicowego oraz ich odniesień do innych orientacji na dwóch członach osi z lewej i prawej strony środka czy też centrum. W badaniach nad ekstremizmem lewicowym zaciążył krytycyzm i wrogość wobec kapitalizmu, przesłaniając inne strony tej odmiany ekstremizmu. Badania nad ekstremizmem prawicowym są bardziej zaawansowane, ponieważ nie doświadczył on wstrząsu dziejowego, jaki dotknął ekstremizm lewicowy, upadku państw socjalistycznych po 1989 roku"s3.

\section{BIBLIOGRAFIA}

Allemeyer B. 1981. Right - Wing Authoritarianism. University of Monitoba Press.

Allemeyer B. 1996. The Authoritarian Specter. Harvard University Press.

Allemeyer B. 2006. The Authoritarians. Lulu.

Amery L. S. 1967. Rządność w demokracji: rozwiązanie brytyjskie. W Demokracja a ideał społeczny. Londyn. 
Antoszewski A. 1998. Reżim polityczny. W Studia z teorii polityki, Jabłoński A., Sobkowiak L. (red.).Wrocław

Arato A. "Dictatorship Before and After Totalitarianism". http//www.encyclopedia.com/doc/1G1-90439542.html

Arendt H. 1989. Korzenie totalitaryzmu. Warszawa.

Arendt H. 1989. Korzenie totalitaryzmu. Warszawa.

Arendt H. 1993. Co to jest autorytet? W Między czasem minionym a przyszłym. Osiem ćwiczeń z myśli politycznej. Warszawa.

Aron R. 1965. Democratie et Totalitarisme. Paris.

Bankowicz Marek. 1996. Słownik polityki. Warszawa.

Bartyzel J. Demokracja, na stronach Internetu.

Baszkiewicz J. 1999. Władza. Ossolineum.

Biernat T. 1999. Legitymizacja władzy politycznej. Elementy teorii. Toruń.

Derczyński W., Jasińska-Kania A., Szacki J. (red.). 1975. Elementy teorii socjologicznych. Warszawa.

Fowler W. (ed.). 1996. Authoritarianism in Latin America since Independence. Westport.

Fraenet E. 1941. The Dual State. A Contribution to the Theory of Dictatorship.

Friedrich C. J. i Brzeziński Z. K. 1956. Totalitarian Dictatorship and Autocracy, Harvard University Press.

Gleason A. 1995. Totalitarianism.

Hallgarten G. 1960. Devils and Saviours. A History of Dictatorship since 600 b C. London.

Held D. 1987. Models of Democracy, Stanford.

Hoffer E. 1951. The True Beliver. Thoughts on the Nature Mass, Movements.

Huntington P. 1995. Trzecia fala demokratyzacji. Warszawa.

Kamenka E. 1998. Totalitaryzm. W Przewodnik po współczesnej filozofii politycznej. Warszawa.

Kariel H. S. 1964. In Search of Authority. Twentieth Century Political Thought. New York.

Kirkpatrick J. 1982. Dictatorship and Double Standards, Rationalism and Reason in Politics.

Kosiakiewicz W. 1913. Spór o terminy polityczne. W Demokracja, demagogia i hemofilia, Warszawa.

Kulesza W. T. 1990. „Fundamenty autorytetu”. Przegląd Tygodniowy (50).

Linz J. J. 1970. Authoritarian Regime: Spain W Mass Politics. Studies in Political Sociology. New York.

Linz J. J. 1975. Totalitarian and Authoritarian Regimes. Reading Mass.

Linz J. J. 1995. Totalitaryzm i autorytaryzm. W Władza i społeczeństwo, wybór i opracowanie Jerzy Szczupaczyński. Warszawa

Linz J. J., Stepan A. 1996. Problems of Democratic Transition and Consolidation. Baltimore.

Lucas C. Global Civil Society v. Totalitarianism. Tekst na stronach Internetu.

Marczewska-Rytko M. 2001. Demokracja bezpośrednia w teorii i praktyce politycznej. Lublin. 
Minich D. 2013. Władza państwowa w koncepcjach Grzegorza Leopolda Seidlera. Rzeszów.

Minoque K. 2005. Co stanowi przeciwieństwo totalitaryzmu? Ośrodek Myśli Politycznej. Tekst na stronach Internetu.

Murray E. 2005. Shut Up: Tale of Totalitarianism.

Page E. C. 1985. Political Authority and Bureaucratic Power. Brighton.

Perdue W. Dan. The New Totalitarianism: Cyber hegemony and the Global System. Tekst na stronach Internetu.

Perlmutter A. 1983. Modern Authoritarianism. A Comparative Institutional Analysis. New Haven.

Ryszka F. 1972. „Autorytaryzm a faszyzm”. Kwartalnik Historyczny (2).

Sartori G. 1971. Appunti per una Teoria Generale della Diktatura.

Satori G. 1994. Teoria demokracji. Warszawa

Schmitt C. 1995. Sytuacja historyczna i stan duchowy dzisiejszego parlamentaryzmu W Konserwatyzm. Projekt teoretyczny. B. Markiewicz (red.). Warszawa.

Seidler G.L. 2000. Władza ustawodawcza i wykonawcza w polskich konstrukcjach ustrojowych 19171947. Lublin.

Shapiro L. B. 1972. Totalitarianism. London.

Simon I. R. 1962. A General Theory of Authority, Notre Dame.

Sokół W. 1996. Dyktatura W Mały Leksykon Politologiczny. Lublin.

Soper S. P.. 1985. Totalitarianism: A Conceptual Approach.

Sruton R. 2005. Źródło totalitaryzmu, Ośrodek Myśli Politycznej. Tekst dostępny na stronach internetu.

Staszewski M. 1938. Demokracja a totalizm, Warszawa.

Talmon J. L. 1952. The Origins of Totalitarian Democracy. London.

Tokarczyk R. 1979. Utopia Nowej Lewicy Amerykańskiej. Warszawa.

Tokarczyk R. 1981. Współczesna amerykańska myśl polityczna. Warszawa.

Tokarczyk R. 1984. „Metody porównawcze w historii doktryn politycznych i prawnych”. Biuletyn Lubelskiego Towarzystwa Naukowego - Humanistyka 26 (2).

Tokarczyk R. 2004. Teoretyczna a praktyczna istota współczesnego ekstremizmu politycznego. W Doktryny współczesnego ekstremizmu politycznego, Edward Olszewski (red.). Lublin

Tokarczyk R. 2008. Komparatystyka prawnicza. wyd. IX. Warszawa.

Tokarczyk R. 2010. Nowa Lewica. Warszawa.

Tokarczyk R. 2010. Współczesne doktryny polityczne, wydanie XVI poszerzone. Warszawa.

Vansittart P. 1995. Dictators to 1995. London.

Wiffogel K. A. 1957. Oriental Despotism: A Comparative Study of Total Power. New Haven.

Wrong D.H. 1988. Power. Its Form, Bases and Uses. Chicago.

Zadencki J. 1995. Wobec despotyzmu wolności. Kraków. Dahl R. 2000. O demokracji. Kraków.

Zdziechowski M. 1923. Europa, Rosja, Azja. Wilno.

Zizek S. 2001. Did Somebody Say Totalitarianism? London. 


\section{LEGITIMACY ISSUES OF ANY POWER AS A CONDITION OF ITS POSITION AND INFLUENCE}

The position and influence of any kind of power, especially state power, depends on the acceptance of its subordinate subjects. This text discusses the main legitimacy issues of the four types of state power - democratic, dictatorship, authoritarian and totalitarian. The etymological meaning of the names given to these powers plays a major role in their variety of interpretations. From a comparative point of view an equally important role is played by knowledge devoted to political extremism.

Keywords: statepower, legitimization, democracy, dictatorship, authoritarianism, totalitarianism, comparative, political extremism

Słowa kluczowe: władza państwowa, legitymizacja, demokracja, dyktatura, autorytaryzm, totalitaryzm, porównanie, polityczny ekstremizm 